\title{
Demographic Development of Russia in the 20th-21st Centuries: Historical and Geopolitical Dimensions
}

\author{
S. V. Ryazantsev ${ }^{a, b, *}$ and L. L. Rybakovskii ${ }^{b, * *, *}$ \\ ${ }^{a}$ Moscow State Institute of International Relations (MGIMO University), Ministry of Foreign Affairs of Russia, \\ Moscow, Russia \\ ${ }^{b}$ Institute for Demographic Research, Federal Center of Theoretical and Applied Sociology, Russian Academy of Sciences, \\ Moscow, Russia \\ *e-mail:riazan@mail.ru \\ **e-mail:1284781@mail.ru
}

Received April 10, 2021; revised April 14, 2021; accepted May 18, 2021

\begin{abstract}
Features of demographic development in Russia from the 1940s to 2020 are retrospectively considered. The stages of the country's demographic development are analyzed, including the contribution of various components to the demographic dynamics in certain historical periods. The idea of distinguishing two waves of depopulation is proposed, and it is argued that the second wave of depopulation in Russia is provoked not only by negative modern trends, but is also associated with the historical features of the demographic development of the country, namely, with the age structure of the population, deformed under the influence of various historical events, or with "demographic pitfalls," often referred to in the literature. The contribution of supermortality to depopulation in the $1990 \mathrm{~s}$, called the shock stage of Russia's demographic development, is highlighted. The features of the second wave of depopulation are noted, which are associated with a decrease in the number of women of reproductive age and a new round of increase in mortality due to COVID-19. A systematic approach to neutralizing the second wave of depopulation is substantiated on the basis of a comprehensive national demographic program, including a system of measures to create conditions for the birth and upbringing of children, support families with children, develop self-preserving behavior, reduce mortality, increase life expectancy, reduce emigration, and attract migrants of the necessary categories to Russia.
\end{abstract}

Keywords: demographic development, Russia, depopulation, components of demographic dynamics, natural increase (decrease), migration gain, human losses, mortality, fertility, demographic policy.

DOI: $10.1134 / \mathrm{S} 1019331621050075$

Against the backdrop of the COVID-19 pandemic, the demographic situation in Russia has deteriorated again. In 2020, according to the Federal State Statistical Service of Russia (Rosstat), the country's population decreased by 510000 people. This was the largest decrease in the last relatively prosperous decade. Recall that at the beginning of 2021, $146.24 \mathrm{mln}$ people lived in the Russian Federation [1]. According to this indicator, the country was in ninth place in the world. In the world table of ranks in terms of population, Bangladesh with its population of $167 \mathrm{mln}$ people is higher than Russia, and Japan $(127 \mathrm{mln})$ is below.

\footnotetext{
\# RAS Corresponding Member Sergei Vasil'evich Ryazantsev is Head of the Department of Demographic and Migration Policy at MGIMO University, Ministry of Foreign Affairs of Russia, and Director of the Institute for Demographic Research, Federal Center of Theoretical and Applied Sociology, Russian Academy of Sciences (IDR FCTAS RAS). Leonid Leonidovich Rybakovskii, Dr. Sci. (Econ.), is Chief Researcher at the IDR FCTAS RAS.
}

Note that Bangladesh is about 120 times smaller than Russia in area!

Domestic and foreign demographic forecasts indicate that the population of the Russian Federation will continue to decline. Thus, according to the UN Population Department, by 2050 it will amount to $129 \mathrm{mln}$ people. This means that Russia will move into the top ten countries in the world for this indicator. According to the UN forecast, countries such as Mexico, Egypt, Ethiopia, the Philippines, and Vietnam will overtake it. Rosstat annually corrects this information according to three options, but it is obvious that the negative dynamics of our population will become dominant in the coming years. Some foreign publications took the opportunity to publish at various times articles on this subject with very expressive headlines: "Rising Ambitions, Sinking Population" (The New York Times, United States), "A Dying Population" (Los Angeles Times, United States), "Russia: A Space without People" (Die Welt, Germany), "The Last Russian" 
(Wprost, Poland), "Russia Doomed to Be the Sick Man of Europe" (The Times, Great Britain), "Why Russia Is Far Less Threatening Than It Seems" (The Washington Post, United States), "Russia's Dangerous Decline" (The Boston Globe, United States), and "The Dying Bear: Russia's Demographic Disaster” (Foreign Affairs, United States).

Regardless of the accuracy of the forecasts, population decline for Russia has negative geopolitical and socioeconomic consequences. It will be difficult to retain and develop vast territories in the East of the country, which are losing residents as a result of mortality and migration outflow. The process of active population decline in Siberia and the Far East can be called nothing other than the "eastern demographic contraction." These particular regions had the maximum human losses between the censuses of 2002 and 2010, although the regions located in Central Russia, the Volga Region, and the Urals found themselves in a similar situation. In addition, the loss of population is noted in small towns and rural settlements, and the shortage of labor resources is aggravated. The number of university entrants and conscripts for the army is decreasing, the share of children and young people is decreasing, and the share of elderly people in the general structure of the population is increasing. According to the economists of Credit Suisse, by 2060 almost half of the population in Russia will be retired, which will require colossal expenses of the Pension Fund. The pension system will have to be reformed in such a way as to finance the growing number of retirees amid a shrinking workforce [2]. Thus, negative demographic trends are becoming more and more sensitive for the Russian economy and society. In addition, the downward dynamics of the population does not add credibility to the country on the world stage.

In these conditions, the Russian authorities are constantly making attempts to activate demographic and migration policies, trying to increase the population from various sources. In 2007, the Concept of Demographic Policy until 2025 was adopted, followed by a set of measures to support the population, including the use of maternity capital. In 2007, the first state program to stimulate the return of compatriots to Russia was launched. Demographic programs have intensified in many regions of the country. In 2005, priority national projects were launched, including "Health." In 2018, the national project "Demography" was adopted. In 2020, the Russian President initiated the development of a Unified Plan for Achieving National Development Goals, which included demographic indicators. Now they are included in the system for assessing the activities of government bodies at different levels, and regional programs for demographic development have been adopted.

These measures made it possible to slightly stabilize the population, the growth dynamics of which has become positive since 2008. Note, however, that immigration, which sharply decreased in 2020 due to the closure of borders, made a significant contribution to the formation of this indicator. At the same time, replenishing the population, migration did not fundamentally solve the demographic problems of the country. All the organizational and financial measures failed to extinguish the second wave of depopulation, which began in Russia in 2016, when the natural decline was 2300 people. Then the flywheel of depopulation began to unwind: in 2017, 135800; in 2018, 224600; in 2019, 317200 ; and in 2020, 688700 (exceeding deaths over births). In addition, the measures of demographic policy did not weaken, but, on the contrary, intensified, and the costs of demographic programs grew. What is the reason for this paradox?

The hypothesis of the research is that the second wave of depopulation in Russia is provoked not only by negative modern trends, but is also associated with the historical features of the country's demographic development, namely, the reciprocal structure of the population deformed under the influence of various historical events, or "demographic pitfalls."

\section{THEORETICAL APPROACHES TO THE CONCEPT OF DEPOPULATION}

The concept of depopulation in the demographic literature is interpreted in different ways. Thus, the Demographic Encyclopedic Dictionary formulates three different definitions of depopulation, associated either with a decrease in the absolute size of the country's population or with its narrowed reproduction. The author of the entry writes that depopulation actually occurs if the value of the general mortality rate exceeds the value of the total birth rate [3, p. 123]. Actually, the same threefold interpretation of depopulation is given in the encyclopedic dictionary Population [4, p. 124].

In the first definition, the depopulation determinants include migratory movement along with natural movement. It is obvious that, even with a high birth rate and low mortality, that is, a significant natural increase, migration can lead to a decrease in the total population. On the contrary, migration can either fully compensate for a natural decline or ensure demographic growth. Migration and natural movement are two determinants of demographic dynamics, and only the second of them can cause depopulation. In turn, migration is an exogenous factor, external to a given population, while natural movement is an endogenous, internal factor.

The second definition of depopulation, to which a number of modern demographers adhere, does not correspond to the essence either. Here is an example. "Strictly speaking," writes V.B. Zhiromskaya, "depopulation is the extinction of the population due to its narrowed reproduction" $[5, \mathrm{p} .8]$. The fact is that the characteristics of population reproduction do not 
relate to processes that are actually taking place but to those that await us in the future. Usually, the levels of population reproduction characterize the total birth rates. These indicators, which, in accordance with modern Russian realities, are at around 2.1-2.15, will characterize the level of simple reproduction of the population. It is clear that if they turn out to be higher than these values, there will be expanded reproduction, and if lower, a narrowed one.

According to the third definition, depopulation is the excess of general mortality rates over similar birth rates. However, depopulation is expressed not only by relative indicators, such as general coefficients, but also by absolute values, in particular, by the excess of the number of deaths over the number of births. Depopulation is one of the states of the country's demographic development the essence of which is a decrease in the population due to its natural decline. In practice, operating with real phenomena, it is precisely the concept of depopulation as an excess of mortality over birth rate that has become firmly established.

Earlier, we proposed and substantiated the term second wave of depopulation as a characteristic of the demographic development of Russian society since 2016 [6]. This stage is characterized by a new round of fertility decline due to the deepening negative changes in the age structure of the population and the exhaustion of fertility reserves caused by the impact of maternity capital measures, which allowed many Russian families to fulfill delayed births. The development of theoretical and practical approaches to assessing the scale and developing measures to compensate for depopulation is also noted at the state level.

Due to the deterioration of the demographic situation in the country, the Presidium of the Council under the Russian President for Strategic Development and National Projects approved on December 24, 2018, the national project "Demography," designed to counter the second wave of depopulation [7]. Now demographic research is faced with the task of identifying its causes and characteristics, as well as possible sociodemographic and geopolitical consequences; allocating reserves to compensate for the decline in the population of the country and its individual regions; and determining possible reserves of compensation for population losses due to migration processes. It is quite obvious that the second wave of depopulation requires the development of new, extraordinary measures of demographic and migration policy, which could help not only compensate for the decline in population but radically reverse demographic trends in Russia in a positive direction.

\section{DEFORMATION OF THE GENDER AND AGE STRUCTURE OF THE POPULATION, 1920s-1980s}

The average annual population growth rate in the RSFSR in the 1921-1940s, despite the dramatic events (collectivization, political terror, mass famine, which swept primarily the Volga regions), amounted to $1.11 \%$. During this time, the RSFSR population increased by $24.8 \%$. The birth rate in that period was 1.5-2 times higher than the death rate. In 1926, there were 43.4 births and 20.7 deaths per 1000 people, and in 1940, 33.0 and 20.6, respectively [7, p. 84]. During the Great Patriotic War, which lasted about 47 months, the Soviet Union lost 27 million people, of which Russia accounted for more than 13 million or more than $48 \%$ of demographic losses. If among the civilian population the share of losses in Russia was two-fifths, in terms of irrecoverable losses of servicemen, it was two-thirds. Until 1943, the main brunt of losses fell on servicemen called up from the regions of Russia free from occupation-from the republics of Central Asia and Trans-Caucasia. In 1941, Russia accounted for $65 \%$ of the Red Army's irrecoverable losses of the USSR total losses; in 1942, 77.1\%; and in $1943,69.5 \%$. As the union republics under occupation were liberated, their contribution to the replenishment of the Soviet Armed Forces increased and, accordingly, the Russia's share in losses decreased. So, in 1945 , it was $50.9 \%$ [8, pp. 164-166].

During the Great Patriotic War, millions of people died, and there were significantly more men than women (the share of men in the population of Russia in 1959 did not exceed $45 \%$ compared to $47 \%$ in 1940 , and women, 55 and $53 \%$, respectively). There was a deformation of the age structure. The share of people aged $10-15$, that is, those who were born during the war and the first postwar years, halved. The proportion of persons born in the 1920 s, that is, the draft contingent of the prewar years, noticeably decreased. The structural changes that took place, the loss of millions of people, primarily men of the most active age, could not but affect the subsequent demographic development of Russia.

There is no reliable information on the dynamics of the population of the war years and the first five years postwar (1946-1950), which was due to the quality of accounting for demographic events in those years, especially in the occupied territories. The same can be said about the migration exchange of the population with a number of countries in connection with changes in state borders and repatriation processes. Statistical bodies began to publish information on the population and other demographic phenomena only in 1950 [7, p. 32; 9, p. 7]. Using the published series of the population of Russia and their components in $1951-1991$, it is possible to reproduce a completely reliable picture of the demographic development of Russia in the postwar Soviet years (Table 1). 
Table 1. Results of natural and migration movement of the population of Russia for five-year periods, 1951-1990, mln people

\begin{tabular}{|c|c|c|c|c|c|c|}
\hline \multirow{3}{*}{\multicolumn{2}{|c|}{$\begin{array}{l}\text { Population at the beginning } \\
\text { of the year }\end{array}$}} & \multirow{4}{*}{$\begin{array}{c}\begin{array}{c}\text { Population } \\
\text { growth } \\
\text { (decline), \% of } \\
\text { previous year }\end{array} \\
-\end{array}$} & \multirow{4}{*}{$\begin{array}{c}\begin{array}{c}\text { Five-year } \\
\text { periods }\end{array} \\
1951-1955\end{array}$} & \multicolumn{3}{|c|}{ Population growth or decline over five years } \\
\hline & & & & \multirow{3}{*}{$\begin{array}{c}\text { total* } \\
9.4\end{array}$} & \multicolumn{2}{|c|}{ including } \\
\hline & & & & & \multirow{2}{*}{$\frac{\text { natural }}{9.2}$} & \multirow{2}{*}{$\frac{\text { migratory }}{0.2}$} \\
\hline 1951 & 102.9 & & & & & \\
\hline 1956 & 112.3 & 109.1 & $1956-1960$ & 8.5 & 9.5 & -1.0 \\
\hline 1961 & 120.8 & 107.6 & $1961-1965$ & 6.4 & 6.9 & -0.5 \\
\hline 1966 & 127.2 & 105.3 & $1966-1970$ & 3.5 & 4.1 & -0.6 \\
\hline 1971 & 130.7 & 102.8 & $1971-1975$ & 4.0 & 4.1 & -0.1 \\
\hline 1976 & 134.7 & 103.1 & $1976-1980$ & 4.3 & 3.7 & 0.6 \\
\hline 1981 & 139.0 & 103.2 & $1981-1985$ & 4.8 & 4.0 & 0.8 \\
\hline 1986 & 143.8 & 103.5 & $1986-1990$ & 4.7 & 3.6 & 1.1 \\
\hline 1991 & 148.5 & 103.3 & 1951-1990 & 45.6 & 45.1 & 0.5 \\
\hline 1991 to 195 & & 144.3 & - & - & - & - \\
\hline
\end{tabular}

Source: [7, pp. 32, 33, 84, 85].

* The total increase is defined as the difference between the population at the end and the beginning of the five-year periods. The migration balance is the difference between total and natural growth.

Table 1 shows numbers in millions, although in those sources where they are taken from, they are given in thousands. This is due to the inaccuracy of information about the natural and migration movement of the population, which are published not only in scientific works but also in statistical reference books. In Soviet times, much statistical data on natural and migration movements, especially after 1976, when almost all information about the population was forbidden to be published in the open press, could only be obtained confidentially. According to the data on the demographic development of Russia from 1951 to 1990, rewritten by the RSFSR Central Statistical Administration (CSA), the total population growth during that period was 45760000 people. The natural increase accounted for 45224000 and, accordingly, the migration increase amounted to 536000 people. These figures do not differ much from those published by the State Statistics Committee of Russia in 1998. Since the differences are small, the numbers, in fact, are almost the same when rounded.

The data generated by the RSFSR CSA in the early 1990s and refined by the State Statistics Committee of Russia at the end of the same decade, in a number of cases, differ from the information that is found in publications that saw the light of day in the 2010s. For example, the natural increase in 1976-1990, according to the RSFSR CSA, was 11212000; according to the State Statistics Committee (Goskomstat) (1998), 11312000 ; according to scientists of the Higher School of Economics (2014), 11317000 [10]; and according to an estimate by L.L. Rybakovskii (2014), 11419000 [11, p. 109]. There are even greater discrepancies in the statistics of population migration. The migration balance in these sources differs by an order of magnitude. For 1951-1955 Rybakovskii's data indicate a migration loss of 670000 people; according to scientists from the Higher School of Economics, 489000; according to Goskomstat, 200000; and according to the RSFSR CSA, 160000 people. The existing discrepancies in the values of the migration balance, as well as the total population growth, are understandable, given its regular updates. However, why the numbers of natural growth, that is, births and deaths, change, remains a mystery.

Over the first 40 years postwar, the population of Russia has increased by $44.3 \%$. In the first half of this period, it increased by 5-9\% every five years, and in the remaining 20 years, by $3-3.5 \%$. The average annual growth rates in the period 1951-1990 decreased slightly compared to the prewar period, although they remained quite high. On average, the number of residents increased by $0.92 \%$ annually. Despite the constant growth, the population of Russia (RSFSR), both in the world population and among the republics of the Soviet Union, steadily declined. If in the early 1950s Russia accounted for a little more than $4 \%$ of the world population; in 1974 it was $3.37 \%$; and in $1990,2.95 \%$. The share of the population of the entire Soviet Union decreased in a similar way (the only exception was 1986-1990) (Table 2). 
Table 2. Change in the number and share of Russia (RSFSR) in the world population and in the USSR from 1950 to 1990 , mln people

\begin{tabular}{|c|c|c|c|c|c|c|}
\hline \multirow{2}{*}{ Years } & \multirow{2}{*}{ World } & \multirow{2}{*}{ USSR } & \multirow{2}{*}{ Russia } & \multirow{2}{*}{$\begin{array}{l}\text { USSR's share in } \\
\text { the world, } \%\end{array}$} & \multicolumn{2}{|c|}{ Russia's share, $\%$} \\
\hline & & & & & in the world & in the USSR \\
\hline 1950 & 2527 & 178.5 & 101.4 & 7.06 & 4.01 & 56.8 \\
\hline 1965 & 3285 & 229.6 & 126.3 & 6.99 & 3.84 & 55.0 \\
\hline 1974 & 3940 & 250.9 & 132.9 & 6.37 & 3.37 & 53.0 \\
\hline 1985 & 4815 & 276.3 & 142.8 & 5.74 & 2.97 & 51.7 \\
\hline 1990 & $5014 *$ & 288.6 & 147.7 & 5.76 & 2.95 & 51.2 \\
\hline
\end{tabular}

Sources: [7, pp. 32, 33]; [9, p. 7]; [12]; [13]; [14].

* Calculated as the weighted arithmetic mean from the data of 1985 and 1992.

Over the first four decades postwar, the population of Russia grew by 45.6 million people (an average of $1-1.15$ million per year), with $98.9 \%$ of the increase accounting for natural movement and only $1.1 \%$ for migration. For 20 years $(1956-1975)$, there was a migration decline in the country, migrants from Russia left for the union republics. This was due to socioeconomic processes. From the 1950s, the development of virgin lands in Kazakhstan began, industrial enterprises and power plants were built in the cities of Central Asia, the social sphere developed, etc. The 1959 census recorded over 2.2 million Russians in the population of the republics of Central Asia, as well as almost four million in Kazakhstan. The Russian population grew in Transcaucasia. But in the second half of the 1970s, a migration inflow into Russia began-a return outflow of Russians.

In the 1950s and the first half of the 1960s, the value of natural increase was largely determined by the high birth rate, which ranged annually from 2.8 million (1951) to 2.3 million (1963). At this time, prewar generations entered their reproductive age, which was not affected by conscriptions and participation in the war. From the mid-1960s, people born during the war years, when the birth rate declined noticeably, began to enter reproductive age. For example, people born in the years 1943-1945 were 36-34 years old in 1979. By that time, there were 2.9 million of them. Those who were born in 1940-1942 and reached the age of 39-37 years in 1979 were 6.4 million. Consequently, in spite of the greater number of years they lived, those born in the two and a half years prewar and the first six months of the war turned out to be 2.2 times more than those born in the two years and six months of the postwar period. The number of births in 1965-1971 was less than 2 million, and in 1973 it was only 1995000 people.

Along with the decline in the birth rate, the number of deaths began to grow. Until the early 1970s, 910 million people died annually; in the period 19691974, 11-12 million; in 1975-1979, 13-14 million; and in the 1980s the number of deaths was 1516.5 million. The number of births increased in the 1980s. This was caused by the implementation of the decree of the USSR Government On Measures to Strengthen State Assistance to Families with Children (1981), which provided for measures to assist young families in acquiring housing; pension benefits for parents; and preschool institutions, as well as onetime and monthly allowances, for children. As a result, in 1982-1988, 2.3-2.5 million people were born annually. The number of births in 1989 was 2.2 million, and in 1990, two million. In the mid-1980s, it increased by 400000-500000 compared to the 1970s. Such a high birth rate ensured an upward demographic dynamics in the country in the postwar years.

One of the main tasks of the decree On Measures to Strengthen State Assistance to Families with Children was the need to extinguish the influence of the demographic wave that arose as a result of a sharp drop in the birth rate during the war years. Successes were noted in 1983-1987, and then the birth rate began to decline, the level of which already in 1989 did not differ from the end of the 1970s. This was followed by a demographic collapse in the 1990s, the main cause of which was a perturbation process that radically changed the socioeconomic structure of society, the country's political system, and the life of the population.

\section{DEMOGRAPHIC SHOCK IN RUSSIAN SOCIETY IN THE 1990s}

The collapse of the Soviet Union in 1991 was accompanied by a radical transformation of the economy (a drop in production, the closure of enterprises, an increase in unemployment), the destruction of the social sphere (health care system, sanitary supervision of food produced), and a deterioration in living conditions of the population (falling incomes, reducing food consumption, lack of confidence in tomorrow). In 1993, the volume of industrial production compared 
Table 3. Fertility rates of Russia's population, 1990-2005

\begin{tabular}{c|c|c|c}
\hline Years & $\begin{array}{c}\text { Number of births, } \\
\text { thousands of people }\end{array}$ & $\begin{array}{c}\text { Per } 1000 \\
\text { population }\end{array}$ & $\begin{array}{c}\text { Total fertility } \\
\text { rate }\end{array}$ \\
\hline 1990 & 1989 & 13.4 & 1.892 \\
1995 & 1364 & 9.3 & 1.337 \\
2000 & 1267 & 8.7 & 1.195 \\
2005 & 1457 & 10.2 & 1.294 \\
\hline
\end{tabular}

Source: [16, pp. 65,91$]$.

to 1989 decreased by $35 \%$. The share of the unemployed in the economically active population in 1992 was $4.7 \%$, and in 1993 it reached 5.5\%. In 1992, in terms of GDP, Russia was in 35th place among 64 compared countries-at the level of Argentina, Thailand, and Colombia [15, pp. 253, 298].

The changes that took place were reflected in the demographic processes: the birth rate continued to decline, and the mortality rate increased sharply. If the number of births decreased relatively monotonically (for nine years from 1990 to 1999 by $39 \%$ ), the number of deaths increased sharply: in 1990, 1656000 (maximum since the early 1950s); in 1993, 2.1 million; and in 1994, 2.3 million. This was an increase of $40 \%$ in four years-an additional 600000 deaths!

The decline in the number of births occurred in parallel with the decline in the total fertility rate: in $1990,1.892$, and by 1999, 1.157. The number of women of reproductive age in the 1990s did not change significantly. However, many young women postponed the realization of their reproductive plans for the future, as they were forced to provide for themselves and sometimes for their husbands and families. For example, the shuttle business employed 10 to 15 million mostly people of young age cohorts, including women. In the 1990s, many people who had fulfilled their reproductive plans in the previous decade, when assistance was provided to families with children, dropped out of the reproductive process. From the beginning of the 2000 s, the number of births and the total fertility rate began to increase (Table 3 ).

The number of deaths in 1993 exceeded 2 million for the first time. The criminal situation in the country sharply worsened, and, accordingly, mortality from external causes increased. In 1990, 21100 murders were registered, and in 1993 there were already 45100 ; that is, the indicators increased 2.1 times. The number of suicides increased from 39200 to 56100 . The consumption of low-quality and counterfeit alcohol and strong alcoholic beverages led to an increase in deaths from 18100 to 52800 [15, pp. 50, 51].

The number of deaths in Russia did not fall below two million for 18 years, until 2011. The maximum figure occurred in 1994, 2002, 2003, and 2005: in these years it exceeded 2.3 million! An increase in the num- ber of deaths with a decrease in the country's population led to an increase in the mortality rate: in 1990, 11.2 per 1000 inhabitants; in 1995, 15.0; in 2000, 15.3; and in 2005, 16.1. A similar downward trend was observed in relation to the indicator of life expectancy of the population: 1990, 69.19; 1995, 64.52; 2000, 65.34; and 2005, 65.37. There were no such low indicators in the history of the country even in the first postwar years.

Thus, the shocking supermortality rate of the 1990s-early 2000s threw Russia back in its demographic development, slowing down the growth of life expectancy and placing it at the level of developing countries. Only in 2011 did the number of deaths drop below two million and begin to decline gradually, reaching a minimum in 2019 (1798000), which corresponded to the level of 1991. At that time, 30 years ago, the population of Russia was larger by 1.5 million (and taking into account Crimea, by 4 million) than in 2019.

\section{IMPROVEMENT OF THE DEMOGRAPHIC SITUATION DURING THE PERIOD OF ACTIVATION OF DEMOGRAPHIC POLICY AND THE SECOND WAVE OF DEPOPULATION}

The improvement of the demographic situation in Russia began in the mid-2000s. Thanks to the implementation of the priority national project "Health" since 2006, primary medical care has been improved, and the availability of high-tech types of treatment has increased, as has the preventive focus of health care; as a result, mortality from preventable causes has decreased. Since 2007, a set of new measures of state assistance to families with children has come into force. The most powerful measure was the maternity capital provided to families at the birth of their second and subsequent children. Support for families during the birth and upbringing of children has increased, and more attention has been paid to the development of obstetric care facilities and to the improvement of medical care for women during pregnancy. The number of benefits for women, including those who do not work, for caring for a child until it reaches the age of one and a half years were increased. All these measures contributed to a decrease in mortality and an increase in the birth rate, which ultimately led, albeit for a short time, to the cessation of natural population decline, that is, overcoming depopulation in Russia (Table 4).

Over the past 30 years, the country's population has declined. By the beginning of 2020, relative to 1991 , it had decreased by 1.6 million people (without Crimea, by 4.1 million). Russia's share in the world population has been steadily decreasing: by $2.7 \%$ in $1992,2.5 \%$ in $1998,2.1 \%$ in 2011 , and $1.9 \%$ in 2020 . In total, it decreased by $0.8 \%$ during this time. If in prerevolutionary times both the population and the share of Russia in the world population grew simultane- 
Table 4. Natural and migratory movement of Russia's population by five-year periods, 1991-2021, mln people

\begin{tabular}{|c|c|c|c|c|c|c|}
\hline \multirow{3}{*}{\multicolumn{2}{|c|}{$\begin{array}{l}\text { Population at the beginning } \\
\text { of the year }\end{array}$}} & \multirow{4}{*}{$\begin{array}{c}\text { Population } \\
\text { growth } \\
\text { (decline), \% of } \\
\text { previous year } \\
-\end{array}$} & \multirow{4}{*}{$\begin{array}{c}\text { Five-year } \\
\text { periods, years }\end{array}$} & \multicolumn{3}{|c|}{ Population growth or decline over five years } \\
\hline & & & & \multirow{3}{*}{$\begin{array}{r}\text { total } \\
18\end{array}$} & \multicolumn{2}{|c|}{ including } \\
\hline & & & & & \multirow{2}{*}{$\begin{array}{c}\text { natural } \\
-2542\end{array}$} & \multirow{2}{*}{$\begin{array}{c}\text { migratory } \\
2560\end{array}$} \\
\hline 1991 & 148.3 & & & & & \\
\hline 1996 & 148.3 & 100.0 & $1996-2000$ & -1988 & -4077 & 2089 \\
\hline 2001 & 146.3 & 98.7 & $2001-2005$ & -3067 & -4377 & 1310 \\
\hline 2006 & 143.2 & 97.9 & $2006-2010$ & -371 & -2008 & 1637 \\
\hline 2011 & 142.9 & 99.8 & $2011-2015$ & 1399 & -43 & 1442 \\
\hline 2016 & 144.2 & 101.0 & $2016-2021$ & -790 & -1367 & $577 * *$ \\
\hline $2020^{*}$ & 144.4 & 100.9 & $1991-2021$ & -4799 & -14414 & 9615 \\
\hline \multicolumn{2}{|c|}{$2020 \%$ of 1991} & 97.4 & - & & & \\
\hline
\end{tabular}

Sources: [7, pp. 32, 33, 84, 85]; [16, p. 21, 65]; [17, p. 15].

* With Crimea 146700.

** Data for January-November 2016.

Table 5. Indicators of the demographic development of Russia in 2016-2020, thousands of people

\begin{tabular}{l|c|c|c|c|c}
\hline \multicolumn{1}{c|}{ Indicators } & 2016 & 2017 & 2018 & 2019 & 2020 \\
\hline Number of births & 1888.7 & 1690.3 & 1604.3 & 1481.1 & 14335.7 \\
Number of deaths & 1891.0 & 1826.1 & 1828.9 & 1798.3 & 2124.5 \\
Natural decline & -2.3 & -135.8 & -224.6 & -317.2 & -688.7 \\
Population at the beginning of the year & 146545 & 146804 & 146880 & 146794 & 146745 \\
\hline
\end{tabular}

Source: data from the Federal State Statistics Service.

ously, in the Soviet years the population grew steadily, although the share of the Soviet Union and Russia in the world population was decreasing. In post-Soviet Russia, both the population and the country's share in the world population are declining. This situation is geopolitically dangerous and is fraught with the loss of a place in the ranks of not only global but also economically significant powers.

Another feature of the dynamics of modern Russia's population is the different role of the components in the demographic dynamics. In the first 40 years postwar, the country's population constantly increased, almost entirely due to natural growth. The share of this component in the period 1951-1990 accounted for $98.9 \%$, and migration, for only $1.1 \%$. In the post-Soviet period, the opposite contribution of these components to the dynamics of the population has developed. In all five-year periods of the 30 years of the post-Soviet period, there has been a small natural increase only four times: in 1991, by 104000 , and in 2013-2015, by a total of 86000 people. In total, Russia has lost 14.4 million people from natural loss over
30 years. However, thanks to the migration component, two-thirds of the natural loss was compensated. As a result, the country's population decreased by only 4.8 million people, and a geopolitical step-the annexation of Crimea-reduced this figure to 2.5 million people.

The worst period in the demographic development of Russia was 1996-2005. Until the mid-2000s, due to the increase in mortality that began after the default of 1998 , the natural decline in the population remained at the level of 840000-850000 people a year. This was the most difficult time of depopulation, followed by a decade of overcoming it and improving the demographic situation in the country, but the improvement did not last long. A new wave of depopulation followed it again. The fundamental difference between this stage of the country's demographic development is that the amount of natural decline is determined solely by the reduction in the number of births, while mortality continues to decline (Table 5).

The onset of depopulation eliminated one of its main features, when the determining factor in natural 
decline was an increase in mortality. In 2020, the number of deaths exceeded 2.1 million; that is, in fact, the figure returned to the level of 1993. However, the reason turned out to be different: the sharp increase in mortality was due to the pandemic caused by the coronavirus. Mortality increased by approximately the excess mortality in Russia in 2020 , which amounted to about 324000 people (or $18 \%$ more than in 2019). The official death rate from COVID-19 in the country during the pandemic was 116000 people, which exacerbated the second wave of depopulation, which began earlier, in 2016.

\section{MEASURES NECESSARY TO OVERCOME DEPOPULATION}

It took Russia 18 years to overcome the depopulation of 1993-2010. The following question arises: how can we solve the problem in the field of fertility? For many years ahead, the birth rate in the country will depend not so much on the low level of the total fertility rate as on the declining number of women of reproductive age. This is a problem for many years, and it can again negatively affect the demographic development of Russia.

Analysis of the demographic situation suggests that a systematic exit from the second wave of depopulation requires a scientifically grounded national demographic program, in which it is advisable to single out measures in four areas.

First, it is necessary to create conditions for the birth and upbringing of children and to support families with children, thus stimulating the birth rate in the country and ensuring natural population growth.

Second, measures should be taken to develop selfpreserving behavior, reduce mortality, and increase life expectancy, which will reduce mortality rates and also ensure natural population growth.

Third, it is necessary to attract migrants of various categories who want to live and work in Russia, which will ensure the growth of the population through migration. In the present conditions, the country should look for a way out by increasing the contribution of the migration component to demographic dynamics. This applies primarily to the remigration of Russians. Calculations of the number of Russians living in the countries of the new abroad show that there may be no more than 13-14 million people. The largest number of them are in Kazakhstan and Ukraine. Unfortunately, these millions can in no way be regarded as potential Russian migration. This is due to their sociodemographic composition. Almost 30 years have passed since the collapse of the Soviet Union. During this time, millions of children were born to the Russian population living in the countries of the new abroad, the socialization of which took place already in new conditions. Moreover, those born in the 1980s also were not socialized under Soviet conditions alone.
Among the most active working age, that is, 2040 years old, the absolute majority are those who were born not in Russia but in the states of permanent residence. About $35-40 \%$ of the entire Russian population may be there, and together with those who are not yet 20 years old, at least three-fifths. Taking into account the above calculations, the value of the migration potential could be $2-4$ million people [18, p. 11].

Fourth, it is necessary to create conditions within the country for the self-realization of the population focused on emigration from Russia, which will additionally ensure migration growth.

In addition, some organizational changes should be made in the structure of demographic and migration policies. As part of the Government of the Russian Federation, it is important to have a Deputy Prime Minister for Social and Demographic Development, as well as separate ministries of demographic development and migration, which should act synchronously for the common goal of increasing the population and improving the quality of human potential in the country.

\section{REFERENCES}

1. A. Kurnosova and A. Batmanova, "The decline in the population of Russia against the pandemic was a record for 15 years," RBK, Jan. 28 (2021). https://www.rbc.ru/economics/28/01/2021/6012a7ca9a7947d4e0e8042d.

2. A. Kholyavko and M. Overchenko, "By 2060, almost half of the population in Russia will be pensioners," Vedomosti, Jan. 23 (2020). https://www.vedomosti.ru/economics/articles/2020/01/22/821263-2060godu.

3. Demographic Encyclopedic Dictionary, Ed. by D. I. Valentei (Sovetskaya Entsiklopediya, Moscow, 1985) [in Russian].

4. V. B. Zhiromskaya, The Main Trends in the Demographic Development of Russia in the 20th Century (Kuchkovo Pole, Moscow, 2012) [in Russian].

5. Population: Encyclopedic Dictionary, Ed. by G. G. Melikyan (Bol'shaya Rossiiskaya Entsiklopediya, Moscow, 1994) [in Russian].

6. Demographic Situation in Russia: New Challenges and Ways of Optimization: National Demographic Report, Ed. by S. V. Ryazantsev (Ekon-Inform, Moscow, 2019) [in Russian].

7. Population of Russia over 100 Years (1897-1997): Statistical Digest (Goskomstat Rossii, Moscow, 1998) [in Russian].

8. L. L. Rybakovskii, The Great Patriotic War: Peculiarities. Human Losses. Victory Factors (Ekon-Inform, Moscow, 2020) [in Russian].

9. Population of the USSR 1973: Statistical Digest (Statistika, Moscow, 1975) [in Russian].

10. Demoslop Weekly, No. 617-618, Nov. 3-16 (2014). http://www.demoscope.ru/weekly/2014/0617/index.php. 
11. Migration Processes in Russia (Ekon-Inform, Moscow, 2014) [in Russian].

12. United Nations Population Division. Department of Economic and Social Affairs. World Population (United Nations, New York, 1985).

13. United Nations Population Division. Department of Economic and Social Affairs. World Population (United Nations, New York, 1992).

14. V. I. Kozlov, Population Dynamics (Nauka, Moscow, 1969) [in Russian].

15. Russian Statistical Yearbook 1994 (Goskomstat Rossii, Moscow, 1994) [in Russian].
16. Demographic Yearbook 2013: Statistical Digest (Rosstat, Moscow, 2013) [in Russian].

17. Demographic Yearbook of Russia 2017: Statistical Digest (Rosstat, Moscow, 2017) [in Russian].

18. Demographic Development of Russia: Trends, Forecasts, Measures: National Demographic Report 2020, Ed. by S. V. Ryazantsev (Ob"edinennaya Redaktsiya, Moscow, 2020) [in Russian].

Translated by B. Alekseev 